\title{
Analisis Stabilitas Parametrik Hasil Cabai Rawit (Capsicum fructescens L.) pada Empat Lokasi Dataran Rendah
}

\section{Parametric Stability Analysis for Yield of Chili (Capsicum fructescens L.) in Four Lowland Environments}

\author{
Juharni $^{1}$, Muhamad Syukur ${ }^{2 *}$, Willy Bayuardi Suwarno², dan Awang Maharijaya² \\ ${ }^{1}$ Program Studi Pemuliaan dan Bioteknologi Tanaman, Sekolah Pascasarjana Insitut Pertanian Bogor \\ ${ }^{2}$ Departemen Agronomi dan Hortikultura, Fakultas Pertanian, Institut Pertanian Bogor \\ (IPB University), Jl. Meranti, Kampus IPB Darmaga, Bogor 16680, Indonesia
}

Diterima 20 Oktober 2020/Disetujui 8 Desember 2020

\begin{abstract}
Stable and high yielding chili varieties are needed to increase national chili production. The objective of this study was to identify the stability of sixteen chili (Capsicum fructescens L.) genotypes using parametric stability analyses (FrancisKannenberg, Wricke, Finlay-Wilkinson, AMMI, and GGE). The study was conducted from August 2018 to September 2019 in Kolaka, Palembang, Aceh, and Bogor. The experiment used a randomized complete block design with three replications. The chili genotypes evaluated were F5285290-237-6-1, F6285290-6-10-1-1, F5285290-290-2-1, F5285290-290-9-1, F5285290290-9-3, F5321290-40-2-1, F5285290-123-6-15, F6321290-252-10-8-4, F5285290-38-6-3, F6321290-252-10-8-23, F6321290-252-10-8-75, Bonita IPB, Inul (local variety), Cakra Putih (commercial variety), Taruna (commercial variety), and Tobasco. The genotype $x$ environment interaction effect was significant on yield. Genotype F6321290-252-10-8-4 was identified as stable based on several parametric stability methods, but this genotype was not the highest yielding. Meanwhile, the GGE analysis revealed Bonita IPB as a stable genotype with the highest yield.
\end{abstract}

Keywords: AMMI, chili, stability analysis, variety

\section{ABSTRAK}

Varietas cabai yang stabil dan berdaya hasil tinggi diperlukan untuk peningkatan produksi cabai nasional. Penelitian ini bertujuan untuk mengevaluasi stabilitas hasil 16 genotipe cabai rawit (Capsicum fructescens L.) dengan menggunakan analisis stabilitas parametrik (Francis-Kannenberg, Wricke, Finlay-Wilkinson, AMMI dan GGE). Penelitian ini dilaksanakan pada bulan Agustus 2018 sampai September 2019 pada empat lokasi, yaitu Kolaka, Palembang, Aceh dan Bogor. Penelitian ini menggunakan rancangan kelompok lengkap teracak dengan tiga ulangan. Genotipe cabai rawit yang dievaluasi adalah F5285290-237-6-1, F6285290-6-10-1-1, F5285290-290-2-1, F5285290-290-9-1, F5285290-290-9-3, F5321290-40-2-1, F5285290-123-6-15, F6321290-252-10-8-4, F5285290-38-6-3, F6321290-252-10-8-23, F6321290-252-10-8-75, Bonita IPB, Inul (varietas lokal), Cakra putih (varietas komersial), Taruna (varietas komersial), dan Tobasco. Interaksi genotipe $x$ lingkungan berpengaruh nyata terhadap hasil. genotipe F6321290-252-10-8-4 diidentifikasi sebagai genotipe stabil berdasarkan beberapa metode stabilitas parametrik, namun genotipe tersebut tidak memiliki rata-rata hasil tertinggi. Sedangkan analisis GGE mengidentifikasi Bonita IPB sebagai genotipe yang stabil dengan daya hasil tertinggi.

Kata kunci: AMMI, analisis stabilitas, cabai rawit, varietas

\section{PENDAHULUAN}

Cabai rawit merah (Capsicum frutescens L.) termasuk salah satu komoditas unggulan Indonesia yang memiliki nilai ekonomi tinggi dan banyak dibudidayakan. Terdapat dua tipe cabai rawit yaitu rawit merah (Capsicum frutescens

\footnotetext{
* Penulis untuk korespondensi. e-mail: muhsyukur@apps.ipb. ac.id
}

L.) dan rawit hijau (Capsicum annuum L.) (Undang et al., 2015; Hakim et al., 2018). Perbedaan keduanya berdasarkan siklus hidup dan tingkat kepedasan rasa. Rawit merah memiliki siklus hidup tahunan (perennial), sedangkan rawit hijau memiliki siklus hidup semusim (annual). Tingkat kepedasan rasa cabai rawit merah lebih pedas dari pada cabai rawit hijau. Tingkat kepedasan tersebut diketahui dari kandungan capsaicin pada rawit merah sebesar 104,300-141,200 Scoville heat unit (SHU) dan rawit hijau sebesar 26,600-39,100 SHU (Sanatombi dan Sharma, 
2008). Komoditas ini memiliki areal pertanaman terbesar di Indonesia, dengan luas pertanaman mencapai 254 ribu hektar (BPS, 2016).

Menurut Badan Pusat Statistik (2019), produktivitas cabai besar nasional Indonesia tahun 2019 adalah 9.10 ton per hektar dan produksi cabai rawit sebesar 7.8 ton per hektar. Angka ini masih rendah jika dibandingkan dengan potensi produktivitasnya yang dapat mencapai 20 ton ha $^{-1}$ (Syukur et al., 2010). Oleh karena itu perbaikan genetik perlu terus dilakukan agar produktivitas cabai di Indonesia maksimal.

Upaya perbaikan genetik untuk mengatasi masalah produktivitas cabai yaitu melalui program pemuliaan tanaman. Perbaikan genetik suatu varietas dengan memanfaatkan potensi genetik dan interaksi genotipe $\mathrm{x}$ lingkungan. Pengaruh interaksi genotipe $\mathrm{x}$ lingkungan tanaman yang besar akan menyebabkan kesulitan dalam pemilihan genotipe harapan yang dikembangkan menjadi varietas baru (Rono et al., 2016). Interaksi ini juga dapat menyebabkan tidak konsistennya ranking genotipe di berbagai lingkungan yang diuji dan meminimalkan besarnya hubungan antara nilai fenotipe dan genotipe (Polizel et al., 2013; Soares et al., 2017). Interaksi genotipe $\mathrm{x}$ lingkungan dapat digunakan oleh pemulia tanaman untuk mengembangkan varietas unggul baru yang spesifik lingkungan atau varietas yang beradaptasi luas.

Varietas yang memiliki adaptasi luas dan stabil dapat mengurangi pengaruh interaksi genotipe $\mathrm{x}$ lingkungan (Barros et al., 2010). Adaptabilitas dan stabilitas suatu genotipe sangat dipengaruhi oleh kondisi lingkungannya (Rahayu et al., 2013). Informasi stabilitas suatu genotipe diperlukan oleh pemulia untuk mengidentifikasi dan memilih genotipe yang berpenampilan baik pada kondisi lingkungan yang diberikan (Jandong et al., 2011).

Analisis stabilitas genotipe dilakukan apabila terdapat pengaruh interaksi antara genotipe dan lingkungan (Sitaresmi et al., 2016). Analisis stabilitas dilakukan untuk mengurai pengaruh interaksi genotipe dan lingkungan secara efektif serta dapat memilah genotipe-genotipe yang stabil dan spesifik lingkungan (Farshadfar et al., 2012). Salah satu pendekatan untuk mempelajari stabilitas suatu genotipe yaitu pendekatan parametrik.

Pendekatan parametrik dapat digunakan apabila asumsi statistik yaitu galat menyebar normal dan pengaruh interaksi dapat terpenuhi dengan baik (Syukur et al., 2012). Beberapa metode parametrik dapat mengidentifkasi genotipe-genotipe yang memiliki stabilitas statis, dan beberapa metode lainnya dapat memberikan informasi tentang stabilitas dinamis. Analisis stabilitas dengan pendekatan parametrik ini antara lain menggunakan metode Wricke's ecovalence (1962), Finlay-Wilkinson (1963), Francis-Kannenberg (1978), AMMI (additive main effect and multiplicative interaction), dan GGE (genotype main effect and genotype by environment interaction).

Metode AMMI digunakan untuk menjelaskan interaksi genotipe dan lingkungan menggunakan analisis komponen utama (principal component analysis). Model ini mampu mengidentifikasi genotipe yang stabil dan menjelaskan hubungan antara genotipe dan lingkungan (Giridhar et al., 2016). Model AMMI menggabungkan classical additive main effects untuk interaksi genotipe $\mathrm{x}$ lingkungan dan multiplicative components menjadi analisis kuadrat terkecil yang terintegrasi sehingga menjadi lebih efektif dalam pemilihan genotipe yang stabil (Dewi et al., 2014; Frutos et al., 2015). Analisis AMMI mampu mengidentifikasi genotipe yang diuji ke dalam dua tipe jenis adapatasi, baik dalam adaptasi luas maupun dalam adaptasi sempit atau spesifik lingkungan (Widyastuti et al., 2013).

Metode analisis AMMI dapat digunakan untuk mengetahui stabilitas hasil dan adaptabilitas setiap galur (Djufry dan Lestari 2012). Metode ini juga efektif digunakan dalam menentukan nilai stabilitas genotipe karena menunjukkan sebagian besar jumlah interaksi genotipe $\mathrm{x}$ lingkungan dan memungkinkan pemisahan antara pengaruh utama dan pengaruh interaksi dan menyediakan interprestasi data (Pacheco et al., 2016). Metode ini dapat digunakan dalam menentukan genotipe-genotipe yang stabil di semua lokasi maupun genotipe-genotipe yang spesifik atau berinteraksi khas dengan lokasi tertentu (Ganefianti et al., 2009). Metode ini digunakan untuk mengidentifikasi genotipe dengan rata-rata hasil yang tinggi dan kemampuan adaptasi yang besar pada lokasi yang diinginkan melalui analisis ragam (ANOVA) dan menggambarkan megaenvironment (Gauch, 2013; Hongyu et al., 2014). Penelitian ini bertujuan untuk mengevaluasi stabilitas hasil 16 genotipe cabai rawit (Capsicum fructescens L.) dengan menggunakan analisis stabilitas parametrik.

\section{BAHAN DAN METODE}

Penelitian dilaksanakan di empat lokasi, yaitu Bogor (Jawa Barat) $250 \mathrm{mdpl}$, Kolaka (Sulawesi Tenggara) $38 \mathrm{mdpl}$, Palembang (Sumatera Selatan) $8 \mathrm{mdpl}$, dan Aceh (NAD) 010 mdpl, dari bulan Agustus 2018 sampai September 2019. Bahan tanaman yang digunakan adalah 16 genotipe galur harapan cabai hasil perakitan Divisi Genetika dan Pemuliaan Tanaman, Departemen Agronomi dan Hortikultura, Fakultas Pertanian IPB, yaitu F5285290-237-6-1, F6285290-6-10-11, F5285290-290-2-1, F5285290-290-9-1, F5285290-2909-3, F5321290-40-2-1, F5285290-123-6-15, F6321290252-10-8-4, F5285290-38-6-3, F6321290-252-10-8-23, F6321290-252-10-8-75, Bonita IPB, Inul (varietas lokal Garut), Cakra Putih (varietas komersial), Taruna (varietas komersial), dan Tobasco.

Penelitian ini dilakukan menggunakan rancangan kelompok lengkap teracak (RKLT) dengan tiga ulangan pada 4 unit lokasi percobaan. Ulangan tersarang dalam lokasi. Setiap satu unit lokasi percobaan terdiri dari 48 satuan percobaan. Setiap satuan percobaan terdiri atas 20 tanaman. Prosedur penelitian dilakukan berdasarkan standar budidaya tanaman cabai. Benih cabai disemai pada tray selama 7 minggu (memiliki 4-5 helai daun), kemudian dipindah tanam dengan jarak tanam $0.5 \mathrm{~m} \times 0.5$ $\mathrm{m}$ dengan kedalaman $20 \mathrm{~cm}$. Lahan diberi kapur dengan dosis 1.5 ton ha ${ }^{-1}$ dan pupuk dasar (Urea $150 \mathrm{~kg} \mathrm{ha}^{-1}$, SP-18 $300 \mathrm{~kg} \mathrm{ha}^{-1}$ dan $\mathrm{KCl} 200 \mathrm{~g} \mathrm{ha}^{-1}$ ) kemudian bedengan ditutup 
dengan mulsa plastik hitam perak. Pemeliharaan meliputi pemasangan ajir pada 2 MST dan pemupukan satu minggu sekali menggunakan larutan pupuk NPK Mutiara (10 g) dan Gandasil (2 $\left.\mathrm{g} \mathrm{L}^{-1}\right)$ dengan dosis $250 \mathrm{~mL}$ per tanaman. Pupuk Gandasil D diaplikasikan saat pertumbuhan vegetatif (daun) dan Gandasil B saat pertumbuhan generatif (bunga). Dilakukan pemotongan tunas air yang tumbuh di titik dikotomus. Pengendalian hama dan penyakit dilakukan 1 minggu sekali dengan penyemprotan menggunakan insektisida Curacron (2 cc $\mathrm{L}^{-1}$ ), dan fungisida Antracol $\left(2 \mathrm{~g} \mathrm{~L}^{-1}\right)$.

Analisis ragam gabungan RKLT diduga dengan model linear sebagai berikut:

$$
\begin{gathered}
Y_{i j k}=\mu+\alpha_{i}+\beta_{j / i}+\tau_{k}+(\tau \alpha)_{k i}+\varepsilon_{i j k} \\
(i=1,2,3,4 ; j=1,2,3 ; k=1,2,3, \ldots 16)
\end{gathered}
$$

dimana $\mathrm{Y}_{\mathrm{ijk}}=$ nilai pengamatan pada lokasi ke-i, ulangan ke-j, genotipe ke-k; $\mu=$ nilai tengah umum; $\alpha_{i}=$ pengaruh lokasi ke-i; $\beta_{\mathrm{j} / \mathrm{i}}=$ pengaruh ulangan ke-j dalam lokasi $\mathrm{ke}-\mathrm{i} ; \tau_{\mathrm{k}}=$ pengaruh genotipe ke-k; $(\tau \alpha)_{\mathrm{ki}}=$ pengaruh interaksi genotipe ke-k dengan lokasi ke-i; $\varepsilon_{\mathrm{ijk}}=$ pengaruh galat percobaan pada lokasi ke-i, ulangan ke-j, genotipe ke-k.

Pemuliaan tanaman menggunakan analisis ragam model acak, model tetap atau kombinasinya dalam mempelajari galur atau genotipe. Model acak digunakan untuk menduga komponen ragam, parameter genetik, dan kemajuan genetik, sedangkan model tetap untuk memilih galur atau varietas untuk pelepasan varietas (Syukur et al., 2015). Dalam sidik ragam gabungan genotipe adalah faktor tetap dan lokasi adalah faktor acak (Tabel 1).

Pendekatan stabilitas parametrik dilakukan dengan menggunakan metode Wricke's ecovalence (1962), FinlayWilkinson (1963), Francis-Kannenberg (1978), AMMI dan GGE. Analisis ini dilakukan pada peubah produksi buah per tanaman (g per tanaman).

Menurut metode Francis-Kannenberg (1978), genotipe yang stabil adalah genotipe yang memiliki koefisien keragaman yang rendah. Koefisien keragaman ini dapat dikategorikan ke dalam empat kelompok, yaitu rendah $(<25 \%)$, agak rendah berkisar antara $(25-50 \%)$, cukup tinggi (50-75\%), dan tinggi (75-100\%) (Moedjono dan Mejaya, 1994).

Finlay dan Wilkinson (1963) menggunakan koefisien regresi dari respon genotipe terhadap indeks lingkungan, $b_{i}$. sebagai parameter stabilitas. Parameter tersebut mengelompokkan genotipe ke dalam tiga kelompok, yaitu (1) $b_{i}=1$ : stabilitas rata-rata (average stability), (2) $b_{i}>1$ : di bawah stabilitas rata-rata (below average stability), dan (3) $b_{i}<1$ : di atas stabilitas rata-rata (above average stability).

\section{HASIL DAN PEMBAHASAN}

Penelitian ini dilaksanakan di empat lokasi dengan kondisi iklim yang bervariasi antar lokasi pengujian. Data iklim menunjukkan bahwa suhu pada setiap lokasi relatif sesuai umtuk pertumbuhan tanaman cabai, namun tingkat curah hujan agak tinggi pada lokasi Bogor dan Palembang, serta kelembaban yang tinggi pada lokasi Palembang (Tabel 2). Suhu udara yang dibutuhkan untuk tanaman cabai adalah 24-30 ${ }^{\circ} \mathrm{C}$ dengan suhu optimal $25^{\circ} \mathrm{C}$. Daya hasil optimal diperoleh pada suhu $18-32{ }^{\circ} \mathrm{C}$ (Bosland and Votava, 2012).

Hasil analisis ragam produktivitas cabai menunjukkan bahwa lingkungan, genotipe dan interaksi genotipe $\mathrm{x}$ lingkungan berpengaruh sangat nyata. Analisis ragam juga menunjukkan bahwa jumlah kuadrat lingkungan berkontribusi sebanyak $60.93 \%$, genotipe berkontribusi $17.26 \%$ dan interaksi genotipe $\mathrm{x}$ lingkungan berkontribusi $21.81 \%$ (Tabel 3). Nzuve et al. (2013) dalam penelitiannya mengemukakan bahwa jumlah kuadrat tengah lokasi yang besar dan nyata menunjukkan keragaman kondisi lingkungan yang menyebabkan keragaman hasil antarlokasi.

Produksi rata-rata cabai masing-masing lingkungan sangat beragam mulai $121.68 \mathrm{~g}$ per tanaman pada lingkungan Palembang hingga $278.08 \mathrm{~g}$ per tanaman pada lingkungan Aceh (Tabel 4). Berdasarkan kondisi lingkungan diketahui bahwa Palembang merupakan lokasi yang memiliki tingkat kelembapan lebih tinggi dibandingkan dengan lokasi lainnya. Kusumah (2010) menyatakan bahwa Tingkat kelembapan yang tinggi mendorong pertumbuhan penyakit tanaman. Penyakit tanaman yang sering terjadi pada kondisi tersebut yaitu penyakit layu fusarium dan antraknosa. Penyakit ini menyebabkan penurunan produksi karena penyebarannya sangat mudah dari satu genotipe ke genotipe yang lain.

Menurut metode Francis-Kannenberg (1978) genotipe yang stabil yang memiliki koefisien keragaman yang rendah yaitu Taruna dan yang agak rendah yaitu Inul, F6321290252-10-8-75, F6321290-252-10-8-23, F5321290-40-2-1, F5285290-123-6-15, dan F6321290-252-10-8-4 (Tabel 5). Lin et al. (1986) menyatakan bahwa analisis stabilitas parametrik Francis-Kannenberg ke dalam konsep stabilitas statis atau biologis. Sulaeman (2012) dalam penelitiannya juga mengemukakan bahwa konsep ini bersifat statis dan hanya melihat respon masing-masing individu terhadap lingkungannya, tanpa ada pembanding langsung terhadap genotipe.

Genotipe yang stabil menurut metode Wricke (1962) adalah yang mempunyai nilai ecovalence $\left(W^{2}\right)$ terkecil

Tabel 1. Garis besar sidik ragam gabungan antar lokasi untuk pengujian genotipe di satu musim (Syukur et al., 2012)

\begin{tabular}{lccc}
\hline $\begin{array}{l}\text { Sumber } \\
\text { keragaman }\end{array}$ & $\begin{array}{c}\text { Derajat } \\
\text { bebas }\end{array}$ & $\begin{array}{c}\text { Kuadrat } \\
\text { tengah }\end{array}$ & F hitung \\
\hline Lokasi (L) & $(1-1)$ & M5 & M5/M4 \\
Ulangan/L & $1(\mathrm{r}-1)$ & M4 & - \\
Genotipe (G) & $(\mathrm{g}-1)$ & M3 & M3/M1 \\
G x L & $(\mathrm{g}-1)(1-1)$ & M2 & M2/M1 \\
Galat & $1(\mathrm{r}-1)(\mathrm{g}-1)$ & M1 & - \\
\hline
\end{tabular}

Keterangan: 1 = banyaknya lokasi; $r$ = banyaknya ulangan; $g=$ banyaknya genotipe 
Tabel 2. Kisaran data suhu, kelembaban relatif dan curah hujan pada empat lingkungan

\begin{tabular}{lccc}
\hline \multirow{2}{*}{ Lokasi } & \multicolumn{3}{c}{ Kondisi iklim } \\
\cline { 2 - 4 } & Suhu $\left({ }^{\circ} \mathrm{C}\right)$ & Kelembaban relatif $(\%)$ & Curah hujan (mm per bulan) \\
\hline Kolaka & $26.90-28.67$ & $74.23-83.45$ & $45.00-263.90$ \\
Palembang & $27.01-28.28$ & $86.00-91.59$ & $96.00-507.20$ \\
Aceh & $26.44-27.59$ & $77.83-84.24$ & $80.70-119.70$ \\
Bogor & $25.79-27.05$ & $81.62-86.50$ & $297.10-679.60$ \\
\hline
\end{tabular}

Tabel 3. Analisis ragam produksi buah per tanaman cabai pada empat lingkungan

\begin{tabular}{|c|c|c|c|c|c|}
\hline Sumber keragaman & $\mathrm{db}$ & $\mathrm{JK}$ & KT & F hitung & Kontribusi (\%) \\
\hline Lingkungan & 3 & $884,920.11$ & $294,973.37$ & $182.21^{* *}$ & 60.93 \\
\hline Ulangan/Lingkungan & 8 & $12,951.09$ & $1,618.89$ & $2.01^{\mathrm{tn}}$ & \\
\hline Genotipe & 15 & $250,626.36$ & $16,708.42$ & $20.79^{* *}$ & 17.26 \\
\hline Genotipe $\mathrm{x}$ Lingkungan & 45 & $316,741.07$ & $7,038.69$ & $8.76^{* *}$ & 21.81 \\
\hline Galat & 120 & $96,433.18$ & 803.61 & & \\
\hline Total & 191 & $1,561,671.82$ & & & \\
\hline
\end{tabular}

Keterangan: $\mathrm{db}=$ derajat bebas; $\mathrm{JK}=$,jumlah kuadrat; $\mathrm{KT}=$ kuadrat tengah, $* * *=$ masing-masing berpengaruh nyata pada taraf 0.05 dan $0.01, \mathrm{tn}=$ tidak berpengaruh nyata

Tabel 4. Rata-rata produksi buah per tanaman cabai pada empat lingkungan

\begin{tabular}{|c|c|c|c|c|c|}
\hline \multirow{2}{*}{ Genotipe } & \multicolumn{4}{|c|}{ Lingkungan } & \multirow{2}{*}{ Rata-rata } \\
\hline & Kolaka & Palembang & Aceh & Bogor & \\
\hline & & & g per tanama & & \\
\hline F5285290-237-6-1 & $104.83 \mathrm{ab}$ & $83.32 \mathrm{~cd}$ & $310.75 \mathrm{bcd}$ & $104.75 \mathrm{ef}$ & $150.91 \mathrm{cde}$ \\
\hline F6285290-6-10-1-1 & $81.89 \mathrm{ab}$ & $79.61 \mathrm{~cd}$ & $246.54 \mathrm{def}$ & $101.15 f$ & $127.29 \mathrm{e}$ \\
\hline F5285290-290-2-1 & $98.22 \mathrm{ab}$ & $125.03 \mathrm{bcd}$ & $370.79 b$ & $237.78 \mathrm{a}$ & $207.96 b$ \\
\hline F5285290-290-9-1 & $97.00 \mathrm{ab}$ & $57.49 \mathrm{~d}$ & $332.92 b c$ & 183.80abcdef & $167.80 \mathrm{bcde}$ \\
\hline F5285290-290-9-3 & $101.22 \mathrm{ab}$ & $83.70 \mathrm{~cd}$ & $265.93 \mathrm{cdef}$ & $117.39 \mathrm{cdef}$ & $142.06 \mathrm{de}$ \\
\hline F5321290-40-2-1 & $110.11 \mathrm{ab}$ & $104.44 \mathrm{bcd}$ & $214.90 \mathrm{ef}$ & $196.20 \mathrm{abc}$ & $156.41 \mathrm{cde}$ \\
\hline F5285290-123-6-15 & $156.33 \mathrm{a}$ & $82.53 \mathrm{~cd}$ & $275.66 \mathrm{cde}$ & $185.45 \mathrm{abcde}$ & $174.99 \mathrm{bcd}$ \\
\hline F6321290-252-10-8-4 & $85.89 \mathrm{ab}$ & $123.88 \mathrm{bcd}$ & $257.47 \mathrm{cdef}$ & $138.40 \mathrm{bcdef}$ & $151.41 \mathrm{cde}$ \\
\hline F5285290-38-6-3 & $87.22 \mathrm{ab}$ & $81.14 \mathrm{~cd}$ & 248.04def & $200.02 \mathrm{abc}$ & 154.11 cde \\
\hline F6321290-252-10-8-23 & $88.89 \mathrm{ab}$ & $127.72 \mathrm{bcd}$ & $197.87 \mathrm{ef}$ & $207.28 \mathrm{ab}$ & $155.44 \mathrm{cde}$ \\
\hline F6321290-252-10-8-75 & $84.83 \mathrm{ab}$ & $159.22 \mathrm{bc}$ & $194.97 \mathrm{ef}$ & $126.32 \mathrm{bcdef}$ & $141.33 \mathrm{de}$ \\
\hline Bonita IPB & $125.00 \mathrm{ab}$ & $284.73 a$ & $535.51 \mathrm{a}$ & $196.11 \mathrm{abc}$ & $285.34 \mathrm{a}$ \\
\hline Inul (Lokal Garut) & $121.61 \mathrm{ab}$ & $167.94 b$ & $262.62 \mathrm{cdef}$ & $190.58 \mathrm{abcd}$ & $185.69 b c$ \\
\hline Cakra Putih & $72.67 b$ & $131.19 \mathrm{bcd}$ & $305.21 \mathrm{bcd}$ & 192.95abcd & $175.50 \mathrm{bcd}$ \\
\hline Tobasco & $84.44 \mathrm{ab}$ & $113.90 \mathrm{bcd}$ & $240.52 \mathrm{def}$ & $112.49 \mathrm{def}$ & $137.84 \mathrm{de}$ \\
\hline Taruna & $155.09 \mathrm{ab}$ & $141.07 \mathrm{bcd}$ & $189.55 f$ & 143.06bcdef & $157.19 \mathrm{cde}$ \\
\hline Rata-rata & $103.45 \mathrm{C}$ & $121.68 \mathrm{C}$ & $278.08 \mathrm{~A}$ & $164.61 \mathrm{~B}$ & \\
\hline
\end{tabular}

Keterangan: Angka yang diikuti huruf kecil yang sama pada kolom yang sama dan angka yang diikuti huruf kapital yang sama pada baris yang sama tidak berbeda nyata berdasarkan uji BNJ taraf 0.05 
(Purbokurniawan et al., 2014; Dewi, 2014). Genotipe yang stabil adalah F6321290-252-10-8-4, selanjutnya diikuti F6285290-6-10-1-1, Tobasco, F5285290-290-93, dan Inul (Tabel 5). Metode ini termasuk dalam konsep stabilitas dinamis atau agronomis. Stabilitas dinamis menunjukkan bahwa genotipe memberikan respon positif terhadap lingkungan dan mampu menyesuaikan daya hasil berdasarkan kisaran tertentu pada lingkungan yang berbedabeda (Becker dan Léon, 1988; Lin et al., 1986; Sabaghnia et al., 2015). Genotipe yang stabil dinamis memiliki daya adaptasi yang mengikuti indeks lingkungan (Mohammadi et al., 2010).

Metode Finlay dan Wilkinson (1963) mengukur stabilitas berdasarkan nilai koefisien regresi $\left(b_{i}\right)$ dari respon suatu genotipe terhadap perubahan indeks lingkungan. Menurut metode ini, genotipe yang stabil adalah yang memiliki nilai $b_{i}=1$ (stabil rata-rata, dimana nilai koefisien regresi tidak berbeda nyata dengan 1). Adapun genotipe yang stabil berdasarkan kriteria ini yaitu F5285290-237-61, F6285290-6-10-1-1, F5285290-290-9-3, F5285290-1236-15, F6321290-252-10-8-4, F5285290-38-6-3, Inul, Cakra Putih, dan Tobasco (Tabel 5). Genotipe yang berada di bawah stabilitas rata-rata $\left(b_{i}>1\right)$ adalah F5285290-290-21, F5285290-290-9-1, dan Bonita IPB, sedangkan genotipe yang berada di atas stabilitas rata-rata $\left(b_{i}<1\right)$ adalah Taruna, F6321290-252-10-8-75, F6321290-252-10-8-23, dan F5321290-40-2-1. Genotipe yang memiliki stabiltas ratarata berdasarkan metode ini digolongkan memiliki stabilitas dinamis, dimana produksi genotipe mengikuti indeks lingkungan. Namun demikian, perlu diperhatikan bahwa stabilitas rata-rata ini bersifat relatif antar genotipe yang dievaluasi dan tidak bersifat umum (Linn et al., 1986). Hal ini antara lain karena indeks lingkungan dihitung berdasarkan rata-rata seluruh genotipe yang diuji, sehingga perubahan ukuran stabilitas dapat terjadi apabila terdapat perubahan set genotipe yang dievaluasi. Stabilitas dinamis atau agronomis menyatakan keragaan rata-rata suatu genotipe pada semua lingkungan (Jambormias dan Riry, 2009).

Berdasarkan hasil analisis korelasi Spearman dapat diketahui bahwa parameter $b_{i}$ berkorelasi positif nyata terhadap $W_{i}$ dan $\sigma_{i}^{2}$ (Tabel 6). Parameter $s^{2} d_{i}$ berkorelasi positif nyata terhadap $W_{i}^{2}, D_{i}, \sigma^{2}$, sedangkan $W^{2}$ berkorelasi positif nyata terhadap $D_{i}$ dan $\sigma_{i}^{2}$. Kusumah (2010) dalam penelitiannya menyatakan bahwa korelasi yang nyata antar parameter stabilitas menunjukkan bahwa parameterparameter stabilitas mengukur aspek stabilitas yang sama dan memungkinkan untuk menggunakan salah satu diantara parameter stabilitas tersebut.

Analisis AMMI dapat dilakukan jika interaksi antara genotipe dan lingkungan nyata. Analisis AMMI menggunakan biplot AMMI sebagai alat visualisasi untuk melihat genotipe-genotipe stabil pada seluruh lingkungan uji atau spesifik pada lingkungan tertentu. Genotipe yang spesifik lingkungan adalah genotipe yang berada jauh dari sumbu utama tetapi letaknya berdekatan dengan garis lingkungan, sedangkan genotipe yang stabil adalah genotipe yang berada dekat dengan sumbu utama $(0,0)$ (Mattjik dan Sumertajaya 2006; Rashidi et al. 2013). Dengan demikian genotipe-genotipe yang stabil di empat lingkungan berdasarkan analisis AMMI yaitu F5285290-237-6-1, F6285290-6-10-1-1, F5285290-290-9-3, F6321290-252-108-4, Inul, Tobasco, dan Cakra Putih. Genotipe yang sesuai

Tabel 5. Analisis stabilitas 16 genotipe cabai rawit pada empat lingkungan

\begin{tabular}{lccccrr}
\hline Genotipe & $Y_{i}$ & $C V_{i}$ & $b_{i}$ & $p_{-} b_{i}$ & $W_{i}^{2}$ & $\sigma_{i}^{2}$ \\
\hline F5285290-237-6-1 & 150.91 & 70.93 & $1.29^{\text {tn }}$ & 0.106 & $5,095.12$ & $5,320.23$ \\
F6285290-6-10-1-1 & 127.29 & 62.91 & $1.00^{\text {tn }}$ & 0.980 & 965.67 & 600.86 \\
F5285290-290-2-1 & 207.96 & 59.75 & $1.56^{* *}$ & 0.003 & $7,264.67$ & $7,799.72$ \\
F5285290-290-9-1 & 167.80 & 72.74 & $1.51^{* *}$ & 0.007 & $7,534.33$ & $8,107.9$ \\
F5285290-290-9-3 & 142.06 & 58.93 & $1.03^{\text {tn }}$ & 0.851 & $1,345.51$ & $1,034.96$ \\
F5321290-40-2-1 & 156.41 & 36.63 & $0.63^{*}$ & 0.046 & $4,887.25$ & $5,082.66$ \\
F5285290-123-6-15 & 174.99 & 45.65 & $0.90^{\text {tn }}$ & 0.566 & $4,510.77$ & $4,652.41$ \\
F6321290-252-10-8-4 & 151.41 & 48.94 & $0.93^{\text {tn }}$ & 0.714 & 458.19 & 20.88 \\
F5285290-38-6-3 & 154.11 & 53.94 & $0.97^{\text {tn }}$ & 0.867 & $3,403.08$ & $3,386.48$ \\
F6321290-252-10-8-23 & 155.44 & 36.55 & $0.55^{*}$ & 0.015 & $7,972.09$ & $8,608.19$ \\
F6321290-252-10-8-75 & 141.33 & 33.22 & $0.48^{* *}$ & 0.005 & $7,503.56$ & $8,072.73$ \\
Bonita IPB & 285.34 & 62.78 & $2.07^{* *}$ & 0.000 & $38,255.95$ & $43,218.32$ \\
Inul (Lokal Garut) & 185.69 & 31.65 & $0.73^{\text {tn }}$ & 0.133 & $1,979.33$ & $1,759.32$ \\
Cakra Putih & 175.50 & 56.66 & $1.24^{\text {tn }}$ & 0.181 & $2,285.25$ & $2,108.96$ \\
Tobasco & 137.84 & 50.63 & $0.86^{\text {tn }}$ & 0.453 & $1,157.49$ & 820.08 \\
Taruna & 157.19 & 14.28 & $0.24^{* *}$ & 0.000 & $10,962.09$ & $12,025.34$ \\
\hline
\end{tabular}

Keterangan: $Y i=$ rata-rata produksi buah per tanaman dari 16 genotipe cabai pada empat lingkungan; $C V i=$ koefisien keragaman; $W^{2} i=$ Wricke ecovalence; $b i=$ koefisien regresi genotipe; $p \_b i=$ nilai $p$ untuk $b i ; \sigma^{2}{ }_{i}=$ ragam stabilitas Shukla; $*^{* * *}=$ masingmasing berbeda nyata dengan 1 pada taraf 0.05 dan $0.01 ; \mathrm{tn}=$ tidak berbeda nyata dengan 1 . 
Tabel 6. Korelasi Spearman antar parameter stabilitas parametrik dan produksi 16 genotipe cabai pada empat lingkungan

\begin{tabular}{|c|c|c|c|c|c|c|}
\hline & $Y_{i}$ & $C V_{i}$ & $b_{i}$ & $s^{2} d_{i}$ & $W_{i}^{2}$ & $D_{i}$ \\
\hline$C V_{i}$ & 0.04 & & & & & \\
\hline$b_{i}$ & -0.40 & -0.10 & & & & \\
\hline$s^{2} d_{i}$ & -0.21 & 0.12 & 0.25 & & & \\
\hline$W_{i}^{2}$ & -0.47 & -0.06 & $0.86^{* *}$ & $0.59^{*}$ & & \\
\hline$D_{i}$ & -0.24 & 0.30 & 0.23 & $0.93^{* *}$ & $0.57^{*}$ & \\
\hline$\sigma_{i}^{2}$ & -0.47 & -0.06 & $0.86^{* *}$ & $0.59^{*}$ & $1.00^{* *}$ & $0.57^{*}$ \\
\hline
\end{tabular}

Keterangan: $Y_{i}=$ rata-rata produksi buah per tanaman dari 16 genotipe cabai pada empat lingkungan; $C V_{i}=$ koefisien keragaman; $b_{i}=$ koefisien regresi; $s^{2} d_{i}=$ deviasi dari regresi; $W_{i}^{2}=$ Wricke's ecovalence; $D_{i}=$ stabilitas genotipe Hanson; $\sigma_{i}^{2}=$ ragam stabilitas Shukla; *** = masing-masing berkorelasi nyata pada taraf 0.05 dan 0.01

ditanam pada lingkungan 1 adalah F6321290-252-10-8-23. Genotipe yang sesuai ditanam pada lingkungan 2 adalah F6321290-252-10-8-75. Genotipe yang sesuai ditanam pada lingkungan 4 adalah F5285290-123-6-15 dan F5285290-386-3 (Gambar 1).

Kontribusi keragaman pengaruh interaksi yang mampu dijelaskan oleh masing-masing komponen AMMI1 dan AMMI2 sebesar $62.1 \%$ dan 24.3\%. Berdasarkan nilai kontribusi keragaman tersebut terlihat bahwa dua komponen tersebut memiliki peranan yang dominan dalam menerangkan keragaman pengaruh interaksi sebesar 86.4 \%. AMMI menggunakan analisis komponen utama (PCA) untuk menvisualisasikan interaksi genotipe $\mathrm{x}$ lingkungan dalam diagram biplot (Sadeghzadeh et al., 2018). Mattos et al. (2013) dan Regis et al. (2018) mengemukakan bahwa proporsi keragaman interaksi genotipe $\mathrm{x}$ lingkungan yang terbesar terdapat pada komponen utama pertama (PC1). Metode AMMI digunakan untuk mengidentifikasi genotipe dengan rata-rata hasil yang tinggi dan kemampuan adaptasi yang besar pada lokasi yang diinginkan melalui analisis ragam (ANOVA) dan menggambarkan mega-environment (Gauch, 2013; Hongyu et al., 2014).

Genotipe yang stabil menurut analisis GGE berbeda dengan analisis AMMI karena AMMI mengacu pada model statistik pengaruh interaksi genotipe x lingkungan (Gauch and Zobel, 1997), sedangkan GGE mengacu pada model statistik pengaruh utama genotipe dan interaksi genotipe $\mathrm{x}$ lingkungan (Yan et al., 2000).

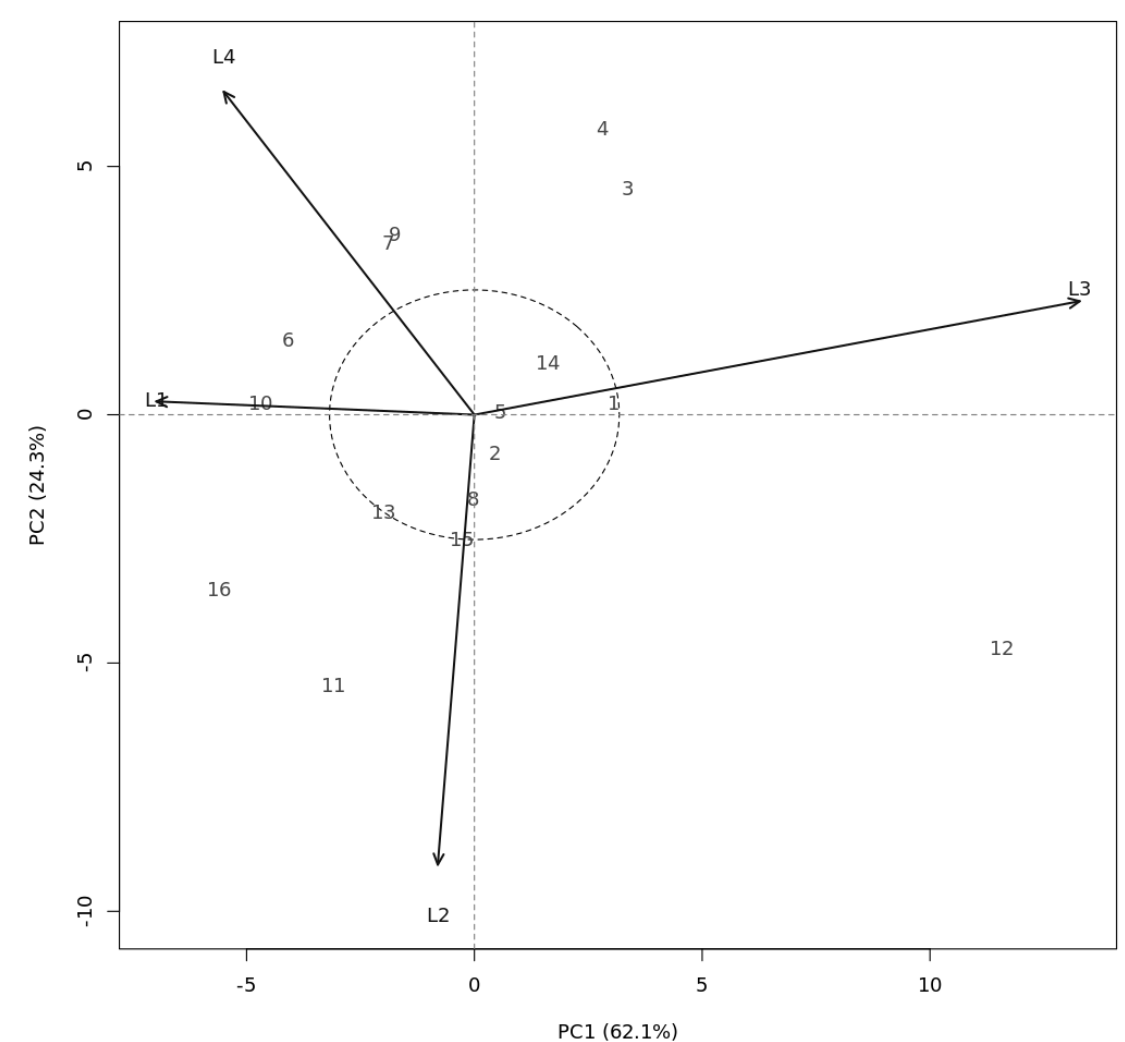

Gambar 1. AMMI biplot PC1 vs PC2 untuk karakter produksi buah 16 genotipe cabai di 4 lokasi (keterangan lihat Gambar 2) 
GGE biplot menghasilkan visualisasi grafik yang menggambarkan penampilan genotipe lingkungan spesifik, adaptabilitas genotipe beberapa lingkungan berbeda, mengidentifikasi genotipe terbaik pada masing-masing lingkungan, memvisualisasikan mega-environment, rata-rata penampilan genotipe dan stabilitasnya. GGE biplot juga mampu menampilkan genotipe terbaik dengan daya hasil tertinggi pada masing-masing mega-environment dan mampu menunjukkan genotipe serta lingkungan ideal (Farshadfar et al., 2013; Farshadfar dan Sadegi, 2014; Susanto et al., 2015).

Yan and Tinker (2005) menyatakan bahwa sumbu AEA (sumbu X) memberikan gambaran rata-rata hasil, sedangkan sumbu Y merupakan garis tegak lurus terhadap sumbu AEA dan melalui titik asal biplot yang memberikan gambaran stabilitas agronomis. Priyanto et al. (2017) dalam penelitiannya mengemukakan bahwa genotipe yang berada di sebelah kanan sumbu Y memiliki hasil lebih tinggi daripada rata-rata semua genotipe, sedangkan di sebelah kiri sumbu Y memiliki hasil di bawah rata-rata seluruh genotipe, serta semakin jauh jarak genotipe dari sumbu $\mathrm{X}$ semakin tidak stabil genotipe tersebut. Berdasarkan teori yang dikemukakan tersebut maka dapat diketahui bahwa hasil rata-rata tertinggi diberikan oleh hibrida Bonita IPB, diikuti oleh F5285290-290-2-1, Inul, dan Cakra Putih. Hibrida Bonita IPB merupakan genotipe yang stabil secara agronomis karena memiliki jarak dekat dengan sumbu X, F5285290-290-2-1 merupakan hibrida yang agak stabil, sedangkan Taruna dan F6321290-252-10-8-75 tidak stabil karena jaraknya jauh dari sumbu X (Gambar 2).

Berdasarkan analisis ragam dapat disimpulkan bahwa interaksi genotipe $\mathrm{x}$ lingkungan secara signifikan berpengaruh terhadap stabilitas hasil. Genotipe yang memiliki stabilitas statis di empat lokasi pengujian dinilai mampu mempertahankan potensi genetiknya (produksi buah per tanaman, yang merupakan dasar untuk analisis stabilitas hasil), sehingga tetap memberikan produksi yang hampir sama pada setiap lokasi pengujian meskipun pengaruh interaksi genotipe $\mathrm{x}$ lingkungan nyata.

Genotipe yang stabil menurut metode stabilitas Wricke (1962) yaitu F6321290-252-10-8-4. Menurut metode Francis-Kannenberg genotipe yang relatif stabil yaitu Taruna, Inul, F6321290-252-10-8-75, F6321290252-10-8-23, F5321290-40-2-1, F5285290-123-6-15, dan F6321290-252-10-8-4. Menurut metode Finlay dan Wilkinson (1963), genotipe yang stabil yaitu F5285290-237-

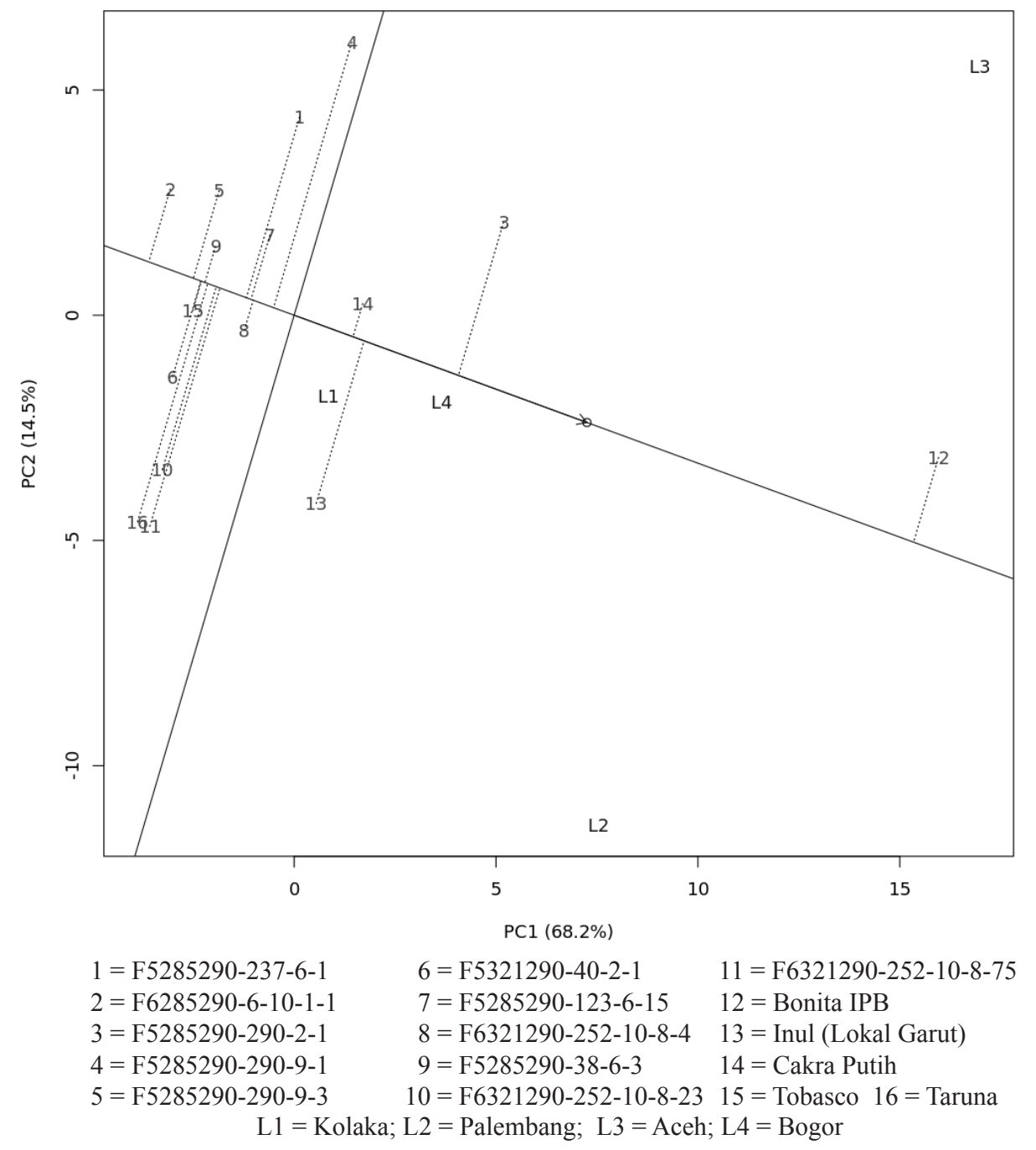

Gambar 2. GGE biplot untuk rata-rata produksi dan stabilitas genotipe cabai di empat lokasi 
6-1, F5285290-290-9-3, F5285290-123-6-15, F6321290252-10-8-4, F5285290-38-6-3, Inul, Cakra Putih, dan Tobasco. Berdasarkan analisis AMMI, keragaman pengaruh interaksi mampu dijelaskan mencapai $86.4 \%$, dan genotipe yang stabil di empat lokasi yaitu F6321290-252-10-8-4, F6285290-6-10-1-1, F5285290-290-9-3, F5285290-2376-1, Cakra Putih, Tobasco dan Inul. Berdasarkan analisis GGE, genotipe yang stabil yaitu Bonita IPB.

\section{KESIMPULAN}

Berdasarkan pendekatan parametrik dengan beberapa metode yang digunakan dalam menganalisis stabilitas, sebagian besar menunjukkan bahwa genotipe yang stabil adalah genotipe F6321290-252-10-8-4. Namun, genotipe tersebut bukan termasuk genotipe yang memiliki nilai rata-rata produksi tertinggi. Sedangkan menurut analisis GGE, genotipe yang stabil yaitu Bonita IPB (genotipe yang memiliki rata-rata produksi tertinggi).

\section{UCAPAN TERIMA KASIH}

Terima kasih disampaikan kepada Kemenristedikti yang telah membiayai penelitian ini melalui Hibah Penelitian Terapan Unggulan Perguruan Tinggi (PTUT) tahun 2018 dan 2019 a.n. Prof Dr Muhamad Syukur SP MSi.

\section{DAFTAR PUSTAKA}

Adie, M.M., Krisnawatit, A.S.G. Wahyu. 2014. Assessment of genotype $\mathrm{x}$ environment interactions for black soybean yield using AMMI and GGE-biplot. Int. J. Agric. Innov. Res. 2:673-78.

Badan Pusat Statistik. 2019. Statistik Tanaman Sayuran dan Buah-buahan Semusim. http://www.bps.go.id/tnmn pgn.php?kat=3 [3 September 2020].

Barros, H.B., T. Sediyatama, C.D. Cruz, R.C. Teixeira, M.S. Reis. 2010. Análise de adaptabilidade e estabilidade em soja (Glycine max L.) em Mato Grosso. Ambiência, Guarapuava. Ambiência Guarapuava (PR). 6:75-88.

Becker, H.C., J. Leon. 1988. Stability analysis in plant breeding. Plant Breed. 101:1-23.

BPS dan Direktorat Jenderal Hortikultura. 2016. Produksi, Luas Panen, dan Produktivitas Sayuran. http://www. bps.go.id/ [3 Juli 2019].

Dewi, A.K., M.A. Chozin, H. Triwidodo, H. Aswidinnoor. 2014. Genotype $\mathrm{x}$ environment interaction and stability analysis in lowland rice promising genotypes. Int. J. Agron. Agric. Res. 5:74-84.

Dewi, S.M. 2014. Keragaan dan Stabilitas Hasil 14 Genotipe Tomat (Solanum lycopersicum L.) di
Empat Lingkungan Dataran Rendah. Tesis. Sekolah Pascasarjana. Institut Pertanian Bogor. Bogor.

Djufry, F., M.S. Lestari. 2012. Stabilitas hasil dan adaptabilitas genotipe jagung hibrida toleran kekeringan menggunakan metode Additive Main Effect Multiplicative Interaction (AMMI). J. Informatika Pertanian 21:51-97.

Francis, T.R., L.W. Kannenberg. 1978. Yield stability studies in short-season maize. A descriptive method for grouping genotypes. Can J. Plant Sci. 58:10291034 .

Farshadfar, E., M.M. Poursiahbidi, M. Jasemi. 2012. Evaluation of phenotypic stability in bread wheat genotypes using GGE-biplot. Int. J. Agri. Crop Sci. 4:904-910.

Farshadfar, E., M. Rashidi, M.M. Jowkar, H. Zali. 2013. GGE biplot analysis of genotype $\mathrm{x}$ environment interaction in chickpea genotype. Euro. J. Exp. Bio. 3:417-423.

Farshadfar, E., M. Sadeghi. 2014. GGE biplot analysis of genotype $\mathrm{x}$ environment interaction in wheatagropyron disomic addition lines. Agric. Commun. 2:1-7.

Finlay, K.W., G.N. Wilkinson. 1963. The analysis of adaptation in plant breeding program. Aust. J. Agric. Res. 14:742-754.

Frutos, E., M.P. Galindo, V. Leiva. 2015. An interactive biplot implementation in $\mathrm{R}$ for modeling genotypeby-environment interaction. Stochastic Environ. Res. Risk Assessment 28:1629-1641.

Gauch, H.G. 2013. A simple protocol for AMMI analysis of yield trials. Crop Sci. 53:1860-1869.

Gauch, H.G., R.W. Zobel. 1997. Identifying megaenvironments and targeting genotypes. Crop. Sci. 37: 311-326.

Ganefianti, D.W., D. Suryati, Hasannudin. 2009. Analisis stabilitas hasil genotipe cabai menggunakan metode additive main effect multiplicative interaction (AMMI). Akta Agrosia 12:147-154.

Giridhar, K., S. Kumari, C. Sarada, N.L. Naram. 2016. Stability for seed yield in ajwain based on gentoype selection index. Indian J. Agric. Res. 50:244-248.

Hakim, A., M. Syukur, Y. Wahyu. 2018. Evaluasi karakter kualitatif dan kuantitatif 20 genotipe cabai rawit merah (Capsicum frutescens L.) koleksi IPB. J. Comm. Horticulturae 2:20-27. 
Hongyu, K., M. García-Peña, L.B. de Araújo, C.T. dos Santos Dias. 2014. Statistical analysis of yield trials by AMMI analysis of genotype $\times$ environment interaction. Biometrical Lett. 51:89-102.

Jambormias, E., J. Riry. 2009. Aplikasi GGE-Biplot untuk evaluasi stabilitas dan adaptasi genotipa-genotipa dengan data percobaan lingkungan ganda. J. Budidaya Pertanian 4:84-93.

Jandong, E.A., M.I. Uguru, B.C. Oyiga. 2011. Determination of yield stability of seven soybean (Glycine max) genotypes across diverse soil $\mathrm{pH}$ levels using GGE biplot analysis. J. Appl. Biosci. 43:2924-2941.

Kusumah, D.A. 2010. Analisis Stabilitas Hasil Cabai Hibrida (Capsicum annuum L.). Tesis. Sekolah Pascasarjana. Institut Pertanian Bogor. Bogor.

Lin, C.S., M.R. Binns, L.P. Levkovitch. 1986. Stability analysis: Where do we stand? Crop Sci. 26:894-900.

Mattjik, A.A., I.M. Sumertajaya. 2006. Perancangan Percobaan dengan Aplikasi SAS dan Minitab. IPB Press, Bogor.

Mattos, P.H.C., R.A.J. Oliveira1, C.B. Filho, E. Daros, M.A.A. Veríssimo. 2013. Evaluation of sugarcane genotypes and production environments in Paraná by GGE biplot and AMMI analysis. Crop Breeding Appl. Biotech. 13:83-90.

Mohammadi, R., M. Roostaei, Y. Ansari, M. Aghaee, A. Amri. 2010. Relationships of phenotypic stability measures for genotypes of three cereal crops. Can. J. Plant Sci. 0:81-830.

Nzuve, F., S. Githiri, D.M. Mukuya, J. Gethi. 2013. Analysis of genotype $\mathrm{x}$ environment interaction for grain yield in maize hybrids. J. Agric. Sci. 5:75-85.

Pacheco, A., M. Vargas, G. Alvarado, F. Rodríguez, M. López, J. Crossa, J. Burgueño. 2016. GEA-R (Genotype Environment Analysis with R for Windows) version 4.0. International Maize and Wheat Improvement Center. 2 Aug 2017.

Polizel, A.C., F.C. Juliatti, O.T. Hamawaki, R.L. Hamawaki, S.L. Guimarães. 2013. Phenotypical adaptability and stability of soybean genotypes in the state of Mato Grosso. Bioscience J. 29:910-920.

Priyanto, S.B., R. Efendi1, Bunyamin Z, M. Azrai, M. Syakir. 2017. Evaluasi stabilitas hasil jagung hibrida menggunakan metode genotype and genotype by environment interaction biplot (GGE biplot). Penelitian Pert. Tan. Pangan 1:97-104.
Purbokurniawan, B.S. Purwoko, D. Wirnas, I.S. Dewi. 2014. Potensi dan stabilitas hasil, serta adaptabilitas galur-galur padi gogo tipe baru hasil kultur antera. J. Agron. Indonesia 42:9-16.

Rahayu, S., A.K. Dewi, Yulidar, D. Wirnas, H. Aswidinnoor. 2013. analisis stabilitas dan adaptabilitas beberapa galur padi dataran tinggi hasil mutasi induksi. A Sci. J. Appl. Isotopes Rad. 9:81-90.

Rashidi, M., E. Farshadfar. M.M. Jowkar. 2013. AMMI analysis of phenotypic stability in chickpea genotypes over stress and non-stress environments. Intl. J. Agri. Crop Sci. 5:253-260.

Regis, J.A.V.B., J.A.C. Andrade, A. Santos, A. Moraes, R.W.R. Trindade, H.J.R. Henriques, L.C. Oliveira. 2018. Adaptability and phenotypic stability of sugarcane clones. Pes. Agro. Bras. 53:42-52.

Rono, J.K., E.K. Cheruiyot, J.O. Othira, V.W. Njuguna, J.K. Macharia, J. Owuoche, M. Oyier, A.M. Kange. 2016. Adaptability and stability study of selected sweet sorghum genotypes for ethanol production under different environments using AMMI analysis and GGE-biplots. Sci. World J. 5:1-14.

Sabaghnia, N., R. Karimizadeh, M. Mohammadi. 2015. Graphic analysis of yield stability in new improved lentil (Lens culinaris Medik.) genotypes using nonparametric statistics. Acta Agric. Slovenica 103:113-127.

Sadeghzadeh, B., R. Mohammadi, H. Ahmadi, G.R. Abediasl, M.M. Ahmadi, M. Mohammadfam, N. Bahrami, M.S. Khaledian, A.A. Naserian. 2018. GGE biplot and AMMI application in the study of adaptability and grain yield stability of durum lines under dryland conditions. Environ. Stresses Crop Sci. 11:241-260.

Sanatombi, K., G.J. Sharma. 2008. Capsaicin content and pungency of different Capsicum spp. cultivars. Not. Bot. Hort. Agrobot. Cluj. 36:89-90.

Sitaresmi, T., C. Gunarsih, Nafisah, Y. Nugraha, B. Abdullah, I. Hanarida, H. Aswidinnoo, I.G.P. Muliarta, A.A. Darajat, dan B. Suprihatno. 2016. Interaksi genotipe $\mathrm{x}$ lingkungan untuk hasil gabah padi sawah. J. Penelitian Pertanian Tanaman Pangan 35:89-98.

Soares, I.O., A.T. Bruzi, E.V. Zambiazzi, S.R. Guilherme, M.C. Bianchi, K.B. Silva, V. Fronza, C.M. Teixeira. 2017. Stability and adaptability of soybean cultivars in Minas Gerais. Genet. Mol. Res. 16:1-7. 
Sulaeman, D.D. 2012. Analisis Stabilitas Hasil dan Keragaan Galur Padi Gogo Hasil Kultur Antera. Tesis. Sekolah Pascasarjana. Institut Pertanian Bogor. Bogor.

Susanto, U., W.R. Rohaeni, S. B. Johnson, A. Jamil. 2015. GGE-Biplot analysis for genotype $\mathrm{x}$ environment interaction on yield trait of high $\mathrm{Fe}$ content rice genotypes in Indonesian irrigated environments. J. Agrivita 37:265-276.

Syukur, M., S. Sujiprihati, R. Yunianti, D.A. Kusumah. 2010. Evaluasi daya hasil cabai hibrida dan daya adaptasinya di empat lokasi dalam dua tahun. J. Agron. Indonesia 38:43-51.

Syukur, M., S. Sujiprihati, R. Yunianti. 2015. Teknik Pemuliaan Tanaman. Penebar Swadaya, Jakarta.

Undang, M. Syukur, Sobir. 2015. Identifikasi spesies cabai (Capsicum spp.) berdasarkan daya silang dan karakter morfologi. J. Agron. Indonesia 43:118-125.
Widyastuti, Y., Satoto, I.A. Rumanti. 2013. Pemanfaatan analisis regresi dan ammi untuk evaluasi stabilitas hasil genotipe padi dan pengaruh interaksi genetik dan lingkungan. Informatika Pertanian 22:21-27.

Wricke, G. 1962. On a method of understanding the biological diversity in field research. Z. Pflanzenzucht 47:92-96.

Yan, W., L.A. Hunt, Q. Sheng, Z. Szlavnics. 2000. Cultivar evaluation and mega-environment investigation based on GGE Biplot. Crop Sci. 40:507-605.

Yan, W., N.A. Tinker. 2005. An integrated analysis system for displaying, interpreting and exploring genotype $\mathrm{x}$ enviroment interaction. Crop Sci. 45:1004-1016. 